\title{
SHORT TITLES, PRIMARY SOURCES
}

Corr. The Correspondence of Edmund Burke. 10 vols. 1958-1978.

Corr. 1844 Correspondence of the Right Honourable Edmund Burke. 4 vols. 1844.

Parl. Hist. The Parliamentary History of England from the Earliest Period to the Year 1803. 36 vols. 1806-1820.

W\&S The Writings and Speeches of Edmund Burke. 9 vols. to date. 1981-.

Works The Works of the Right Honourable Edmund Burke. 16 vols. 1808-1827. 
